\title{
RAS-Related Protein Rap-1A
}

National Cancer Institute

\section{Source}

National Cancer Institute. RAS-Related Protein Rap-1A. NCI Thesaurus. Code C29763.

Ras-related protein Rap-1A (184 aa, $\sim 21 \mathrm{kDa}$ ) is encoded by the human RAP1A gene. This protein is involved in competitive inhibition of Ras signaling. 